\title{
High-resolution monitoring of nutrients in groundwater and surface waters: process understanding, quantification of loads and concentrations, and management applications
}

\author{
Frans C. van Geer ${ }^{1,2}$, Brian Kronvang ${ }^{3}$, and Hans Peter Broers ${ }^{1}$ \\ ${ }^{1}$ TNO - Geological Survey of the Netherlands, P.O. Box 80015, 3508 TA Utrecht, the Netherlands \\ ${ }^{2}$ Department of Physical Geography, Faculty of Geosciences, Utrecht University, P.O. Box 80115, \\ 3508 TC Utrecht, the Netherlands \\ ${ }^{3}$ Department of Bioscience, Aarhus University, Vejlsøvej 25, 8600 Silkeborg, Denmark \\ Correspondence to: Brian Kronvang (bkr@bios.au.dk) and Hans Peter Broers (hans-peter.broers@tno.nl) \\ Received: 12 April 2016 - Published in Hydrol. Earth Syst. Sci. Discuss.: 12 May 2016 \\ Revised: 11 July 2016 - Accepted: 18 August 2016 - Published: 7 September 2016
}

\begin{abstract}
Four sessions on "Monitoring Strategies: temporal trends in groundwater and surface water quality and quantity" at the EGU conferences in 2012, 2013, 2014, and 2015 and a special issue of HESS form the background for this overview of the current state of high-resolution monitoring of nutrients. The overview includes a summary of technologies applied in high-frequency monitoring of nutrients in the special issue. Moreover, we present a new assessment of the objectives behind high-frequency monitoring as classified into three main groups: (i) improved understanding of the underlying hydrological, chemical, and biological processes (PU); (ii) quantification of true nutrient concentrations and loads (Q); and (iii) operational management, including evaluation of the effects of mitigation measures (M). The contributions in the special issue focus on the implementation of high-frequency monitoring within the broader context of policy making and management of water in Europe for support of EU directives such as the Water Framework Directive, the Groundwater Directive, and the Nitrates Directive. The overview presented enabled us to highlight the typical objectives encountered in the application of highfrequency monitoring and to reflect on future developments and research needs in this growing field of expertise.
\end{abstract}

\section{Introduction}

The presence and dynamic behaviour of nutrients in groundwater and surface water is an important issue in water management, in particular in areas with intensive agriculture. This is, for example, reflected in EU directives such as the Nitrates Directive (EU, 1991), the Water Framework Directive (WFD; EU, 2000), the Groundwater Directive (GWD; EU, 2006), and the Monitoring Directive (EU, 2009). Member states are obliged to monitor and report on the environmental status of the water bodies and, if necessary, take measures to establish adverse trend reversal. As far as nutrients are concerned, the European directives focus on aquatic ecosystems and groundwater-dependent ecosystems. In order to meet the obligations, monitoring programmes have to cover a range of water quantity, water quality, and ecological parameters, and an understanding of dynamic nutrient processes is required for these programmes to be efficient and cost-effective. However, the design of monitoring strategies is often hampered by limited knowledge of, for instance, nutrient responses to weather conditions, land use, and agricultural practices. Moreover, the behaviour of nutrients shows large variability in both space and time (see, e.g., Campbell et al., 2015; Goyenola et al., 2015).

To satisfy the increasing demand for knowledge and information on the dynamic behaviour of nutrients, the past 10-15 years have seen a rapid development of observation devices and technologies for high-resolution monitoring of nutrients and other solutes and isotopes at affordable cost, 
encouraging researchers, and other stakeholders to perform studies in experimental as well as operational settings. Thus, vast amounts of research data have been collected on various water quality variables, allowing the study of relevant biogeochemical processes and enabling comparisons between the results obtained by the use of different monitoring devices. Thus, awareness has increased about the advantage of using high-resolution nutrient monitoring as a complementary tool next to traditional low-frequency monitoring. The sessions on "Monitoring Strategies: temporal trends in groundwater and surface water quality and quantity" at the EGU conferences in 2012, 2013, 2014, and 2015 clearly showed that high-frequency monitoring and strategies for nutrient monitoring are subjects that attract great interest. Part of the work presented at these sessions is now gathered in the 10 papers included in this special issue of HESS, which aims to provide an overview of the current state of high-resolution monitoring of nutrients, to identify important knowledge gaps and to pinpoint future research needs and potential application of high-resolution monitoring in the management of groundwater and surface water resources. The main research questions addressed are the following:

- What does the new monitoring technology have to offer and how can we develop an optimal monitoring strategy?

- Can we assess and quantify the transport processes of nutrients, in particular at a short timescale?

- How can we use high-frequency nutrient monitoring to achieve our management goals?

\section{Monitoring objectives}

An overview of monitoring objectives and timescales for high-frequency nutrient monitoring is given in Table 1 . We distinguished between three main groups of monitoring objectives:

1. to improve our understanding of the underlying hydrological, chemical, and biological processes determining temporal and spatial patterns in nutrients (process understanding: PU);

2. to quantify nutrient loads and concentrations (quantification: Q);

3. to support operational water and environmental management, including evaluation of the effects of mitigation measures and predictions (management: $\mathrm{M}$ ).

It should be noted that some papers address more than one of these overall objectives.

\subsection{Objective 1: hydrological, chemical, and biological process understanding}

Kirchner et al. (2004) addressed the new opportunities of high-resolution monitoring for understanding the functioning of catchments, and they foresaw a new era of technical progress and study of actual data, making full profit of the newly acquired spectrum of signals from very short to longer timescales. A decade later, a large number of papers and presentations, including those at the EGU sessions, have demonstrated that process understanding has indeed improved significantly. We have made a subdivision of the monitoring objectives focusing on process understanding (PU):

- PU1: understanding flow regimes and nutrient dynam$i c s$. These studies focus on the behaviour of one variable at a time in order to characterize flow regimes, flow and concentration dynamics, hysteresis effects, and extreme values of nutrient concentrations and loads. Typically, high-frequency monitoring via its high resolution allows characterization of the concentration changes. Thus, the rising limb of the hydrograph represents the short-scale transport processes. Examples can be found in Goyenola et al. (2015) and Outram et al. (2014).

- PU2: characterization of transport routes and timescales. These studies aim to detect flow routes, groundwater-surface water interactions, and travel time distributions with emphasis on the interactions between variables in different hydrological compartments, in particular those between groundwater and surface water. The added value of high-frequency monitoring is its ability to distinguish between fast and slow flow components (see Poulsen et al., 2015b; Shreshta et al., 2013; Rozemeijer et al., 2010a, 2012). High-frequency monitoring has also stimulated the development of new approaches to characterize the transient nature of travel time distributions (Van der Velde et al., 2010; Botter et al., 2011; Hrachowitz et al., 2015).

- PU3: characterization of retention processes. These studies aim to gain insight into the attenuation and retention processes determining the response of nutrients to driving forces such as rainfall events, in both surface water and groundwater. High-frequency monitoring may, for example, reveal clear day-night cycles in nutrient concentrations, contributing to the unravelling of retention and primary production processes in surface waters (see, e.g., Rode et al., 2013). Quantifying denitrification processes using $\mathrm{N}$-isotopes together with calibration of flow models using nitrate and discharge data is a promising approach when studying PU2 and PU3 objectives combined (Shershta et al., 2013). 
Table 1. Overview of monitoring objectives and timescales for high-frequency nutrient monitoring.

\begin{tabular}{|c|c|c|c|}
\hline $\begin{array}{l}\text { Bold references appear in this } \\
\text { special issue }\end{array}$ & $\begin{array}{l}\text { Short-scale dynamics } \\
\text { and extreme events } \\
\text { (minutes to weeks) }\end{array}$ & $\begin{array}{l}\text { Seasonal and annual } \\
\text { patterns (months to } \\
\text { several years) }\end{array}$ & $\begin{array}{l}\text { Longer-term behaviour } \\
\text { and trends (years to } \\
\text { decades) }\end{array}$ \\
\hline \multicolumn{4}{|c|}{ Hydrological, chemical, and biological process understanding (PU) } \\
\hline $\begin{array}{l}\text { PU1: flow regimes and } \\
\text { dynamics, hysteresis } \\
\text { effects, extremes }\end{array}$ & $\begin{array}{l}\text { Poulsen et al. (2015b) } \\
\text { Poulsen et al. (2015a) } \\
\text { Outram et al. (2014) } \\
\text { Jordan et al. (2014) } \\
\text { Wade et al. (2012a, b) } \\
\text { Oosterwoud et al. (2014) } \\
\text { Neal et al. (2012) } \\
\text { Kirchner et al. (2004) }\end{array}$ & $\begin{array}{l}\text { Goyenola et al. (2015) } \\
\text { Van der Grift et al. }(2016) \\
\text { Halliday et al. }(2014 a, b) \\
\text { Jordan et al. }(2012) \\
\text { Neal et al. }(2011,2012) \\
\text { Neal et al. }(2011)\end{array}$ & Neal et al. (2011) \\
\hline $\begin{array}{l}\text { PU2: detection of flow } \\
\text { routes, groundwater- } \\
\text { surface water } \\
\text { interactions, travel time } \\
\text { distributions }\end{array}$ & $\begin{array}{l}\text { Rozemeijer et al. (2012) } \\
\text { Van der Velde et al. (2010) } \\
\text { Wade et al. (2013) } \\
\text { Kirchner et al. (2004) }\end{array}$ & $\begin{array}{l}\text { Poulsen et al. (2015b) } \\
\text { Shrestha et al. (2013) } \\
\text { Van der Velde and Rozemeijer (2012) } \\
\text { Van der Vlugt et al. (2014) } \\
\text { Yu et al. (2015) } \\
\text { Neal et al. (2011) }\end{array}$ & \\
\hline $\begin{array}{l}\text { PU3: attenuation and } \\
\text { retention processes - } \\
\text { surface water and groundwater }\end{array}$ & $\begin{array}{l}\text { Rode et al. }(2012,2013) \\
\text { Bieroza and Heathwaite (2013) } \\
\text { Halliday et al. (2014a) } \\
\text { Neal et al. (2012) } \\
\text { Kirchner et al. (2004) }\end{array}$ & $\begin{array}{l}\text { Rode et al. }(2012,2013,2014) \\
\text { Shrestha et al. }(2013) \\
\text { Windolf et al. }(2011) \\
\text { Wade et al. }(2012 \mathrm{a}, \mathrm{b}) \\
\text { Halliday et al. }(2014 \mathrm{a}) \\
\text { Neal et al. }(2011,2012)\end{array}$ & Ernstsen et al. (2015) \\
\hline \multicolumn{4}{|c|}{ Quantification of loads and concentrations (Q) } \\
\hline $\begin{array}{l}\text { Q1: assessment of } \\
\text { concentrations, loads, } \\
\text { export to downstream } \\
\text { waters (lakes, rivers, } \\
\text { estuaries) }\end{array}$ & $\begin{array}{l}\text { Campbell et al. (2015) } \\
\text { Graeber et al. (2015) } \\
\text { Wade et al. (2012a, b) } \\
\text { Lloyd et al. (2012) } \\
\text { Jordan et al. (2014) } \\
\text { Ovesen et al. (2012, 2013) } \\
\text { Rozemeijer et al. (2010a, b, 2013) } \\
\text { Halliday et al. (2012) } \\
\text { Cassidy and Jordan (2011) }\end{array}$ & $\begin{array}{l}\text { Campbell et al. (2015) } \\
\text { Ernstsen et al. (2015) } \\
\text { Goyenola et al. (2015) } \\
\text { Graeber et al. (2015) } \\
\text { Van der Grift et al. (2016) } \\
\text { Rozemeijer et al. (2016) } \\
\text { Wade et al. (2012a) } \\
\text { Halliday et al. (2012) } \\
\text { Lloyd et al. (2012) } \\
\text { Ovesen et al. (2013) } \\
\text { Bieroza et al. (2013, 2014) } \\
\text { Jordan et al. (2012, 2014) } \\
\text { Oosterwoud et al. (2014) } \\
\text { Poulsen et al. (2014) } \\
\text { Yu et al. (2015) }\end{array}$ & $\begin{array}{l}\text { Ernstsen et al. (2015) } \\
\text { Windolf et al. (2014) } \\
\text { Kronvang et al. (2013) } \\
\text { Greene et al. (2011) }\end{array}$ \\
\hline $\begin{array}{l}\text { Q2: trend assessment, } \\
\text { slopes, and directions }\end{array}$ & $\begin{array}{l}\text { Aubert et al. (2013) } \\
\text { Lloyd et al. (2014) }\end{array}$ & $\begin{array}{l}\text { Van der Grift et al. (2016) } \\
\text { Aubert et al. (2013) } \\
\text { Kirchner (2004) } \\
\text { Lloyd et al. (2014) } \\
\text { Blauw et al. (2013) } \\
\text { Jordan et al. (2014) }\end{array}$ & $\begin{array}{l}\text { Aubert et al. (2013) } \\
\text { Halliday et al. (2012, 2014a) } \\
\text { Windolf et al. (2013, 2014) } \\
\text { Rozemeijer et al. (2014) } \\
\text { Broers (2002) } \\
\text { Hansen et al. (2012a, b, 2013) } \\
\text { Broers and Van der Grift (2004) } \\
\text { Visser et al. (2007, 2009) } \\
\text { Neal et al. (2011) }\end{array}$ \\
\hline $\begin{array}{l}\text { Q3: probability of } \\
\text { exceedance, compliance } \\
\text { with water quality } \\
\text { standards }\end{array}$ & $\begin{array}{l}\text { Skeffington et al. (2015) } \\
\text { Campbell et al. (2015) } \\
\text { Audet et al. (2014) } \\
\text { Halliday et al. (2014b) } \\
\text { Lloyd et al. (2013) } \\
\text { Rode et al. (2014) }\end{array}$ & $\begin{array}{l}\text { Skeffington et al. (2015) } \\
\text { Ernstsen et al. }(2015) \\
\text { Bieroza et al. }(2013,2014) \\
\text { Lloyd et al. }(2012,2013) \\
\text { Jonczyk et al. }(2014)\end{array}$ & $\begin{array}{l}\text { Ernstsen et al. (2015) } \\
\text { Halliday et al. (2014a) }\end{array}$ \\
\hline $\begin{array}{l}\text { Q4: water and matter } \\
\text { balances, sources } \\
\text { apportionment }\end{array}$ & $\begin{array}{l}\text { Rode et al. (2014) } \\
\text { Rozemeijer et al. }(2010 b) \\
\text { Aubert et al. }(2013,2014)\end{array}$ & $\begin{array}{l}\text { Graeber et al. (2015) } \\
\text { Goyenola et al. (2015) } \\
\text { Van der Grift et al. (2016) } \\
\text { Greene et al. (2011) } \\
\text { Rozemeijer et al. (2010b) } \\
\text { Aubert et al. (2013, 2014) } \\
\text { Wade et al. (2012a, b) } \\
\text { Jordan et al. (2014) } \\
\text { Poulsen et al. (2014, 2015a) } \\
\text { Van der Vlugt et al. (2014) } \\
\text { Yu et al. (2015) }\end{array}$ & $\begin{array}{l}\text { Ernstsen et al. (2015) } \\
\text { Greene et al. (2011) }\end{array}$ \\
\hline
\end{tabular}


Table 1. Continued.

\begin{tabular}{|c|c|c|c|}
\hline $\begin{array}{l}\text { Bold references appear in this } \\
\text { special issue }\end{array}$ & $\begin{array}{l}\text { Short-scale dynamics } \\
\text { and extreme events } \\
\text { (minutes to weeks) }\end{array}$ & $\begin{array}{l}\text { Seasonal and annual } \\
\text { patterns (months to } \\
\text { several years) }\end{array}$ & $\begin{array}{l}\text { Longer-term behaviour } \\
\text { and trends (years to } \\
\text { decades) }\end{array}$ \\
\hline $\begin{array}{l}\text { Q5: test and comparison } \\
\text { of equipment }\end{array}$ & $\begin{array}{l}\text { Huebsch et al. (2015) } \\
\text { Audet et al. (2014) } \\
\text { Faucheux et al. (2013) } \\
\text { Oosterwoud et al. (2014) } \\
\text { Wade et al. (2012a) } \\
\text { Cassidy et al. (2012) } \\
\text { Schneider et al. (2012) } \\
\text { Stadler et al. (2015) } \\
\text { Jomaa et al. (2015) } \\
\text { Heinz et al. (2014) }\end{array}$ & $\begin{array}{l}\text { De Jonge et al. (2012) } \\
\text { Vendelboe et al. (2015) } \\
\text { Jordan et al. (2013) } \\
\text { Rozemeijer et al. (2010c, 2013) } \\
\text { Cassidy et al. (2012) }\end{array}$ & \\
\hline \multicolumn{4}{|c|}{ Operational (real-time) management - effects and predictions (M) } \\
\hline $\begin{array}{l}\text { M1: management and } \\
\text { mitigation of point } \\
\text { sources }\end{array}$ & Campbell et al. (2015) & Jordan et al. (2012) & Greene et al. (2011) \\
\hline $\begin{array}{l}\text { M2: management and } \\
\text { mitigation of diffuse } \\
\text { sources, land use } \\
\text { management }\end{array}$ & $\begin{array}{l}\text { Campbell et al. (2015) } \\
\text { Melland et al. (2012) } \\
\text { Heinz et al. (2014) }\end{array}$ & $\begin{array}{l}\text { Rozemeijer et al. (2016) } \\
\text { Campbell et al. (2015) } \\
\text { Melland et al. (2013) } \\
\text { Jordan et al. (2012) } \\
\text { Quinn et al. (2015) }\end{array}$ & $\begin{array}{l}\text { Ernstsen et al. (2015) } \\
\text { Windolf et al. (2014) } \\
\text { Greene et al. (2011) }\end{array}$ \\
\hline $\begin{array}{l}\text { M3: climate change } \\
\text { impacts and adaptations }\end{array}$ & $\begin{array}{l}\text { Graeber et al. (2015) } \\
\text { Goyenola et al. (2015) } \\
\text { Graeber et al. (2014) }\end{array}$ & $\begin{array}{l}\text { Graeber et al. (2015) } \\
\text { Goyenola et al. (2015) } \\
\text { Graeber et al. (2014) }\end{array}$ & \\
\hline
\end{tabular}

\subsection{Objective 2: quantification of loads and concentrations}

Quantification (Q) type monitoring objectives focus not on identifying and understanding the processes but on the quantification of specified quantities, such as averages, probabilities, and proportions of exceedance of water quality standards. Typically, such objectives relate to policy development and operational management, in particular relative to EU directives such as the EU Nitrates Directive (EU, 1991) and the Water Framework Directive (EU, 2000). Q type objectives are divided into five categories:

- Q1: assessment of typical or average concentrations, solute loads, and export of solutes towards downstream waters. Low-frequency monitoring can give an estimate of average concentrations and discharges over a time period via interpolation. However, nutrient concentrations and discharges are frequently correlated. Shortduration concentration peaks likely go undetected using low-frequency monitoring, which implies that load estimates based on low-frequency monitoring are typically biased and too low (Rozemeijer et al., 2010a; Cassidy and Jordan, 2011; Audet et al., 2014; Goyenola et al., 2015; Skeffington et al., 2015). In contrast, highfrequency monitoring reduces the bias in concentration distributions derived from under-sampling of the concentration time series (e.g. Jordan et al., 2007; Roze- meijer et al., 2010b; Ernstsen et al., 2015; Campbell et al., 2015). High-frequency monitoring may also reveal artefacts produced by the fact that regular sampling is normally undertaken in the daytime, thus typically not capturing differences between daytime and night-time fluxes (Neal et al., 2012; Van der Grift et al., 2016).

- Q2: assessment of temporal trends, quantification of trend slopes and identification of trend directions. Highresolution monitoring, in combination with time series from regular low-frequency monitoring, may help to reveal the structure of water quality time series, thereby allowing testing the significance of trends both deterministically (e.g. Van der Grift et al., 2016) and statistically (Lloyd et al., 2014; Rozemeijer et al., 2014), for example using spectral analysis methods (Aubert et al., 2013, 2014; Blauw et al., 2013).

- Q3: testing compliance with water quality standards, such as WFD environmental quality standards. This involves testing the frequency of exceedance of standards or quantifying the probability of exceedance. Highfrequency monitoring improves these aims by adding information on extreme values and short-term peaks impacting the regular evaluation of exceedances in lowfrequency programmes. Skeffington et al. (2015) clearly demonstrate that the classification of WFD Chemical and Ecological Status is strongly influenced by sam- 
pling frequency and time of sampling during the year and over the day.

- Q4: water and matter balances and sources. Detection of (pollution) sources is often difficult to capture in natural catchment systems, but high-frequency monitoring can add short timescale information on dilution or accumulation rates, which helps source apportionment and adds to improving water and mass balances (see Van der Grift et al., 2016; Aubert et al., 2013; Goyenola et al., 2015; Rozemeijer et al., 2010b).

- Q5: comparison of monitoring equipment. Several recent studies endeavour to answer the question of how high-frequency monitoring equipment may supplement the existing monitoring tools. The central question is "what are the possibilities of new equipment?". Examples of comparisons of new monitoring equipment used in surface water and groundwater monitoring are found in Audet et al. (2014), Huebsch et al. (2015), Jordan et al. (2013), and Rozemeijer et al. (2010c).

\subsection{Objective 3: operational (real-time) management - effects and predictions}

The central aim of the management (M) type monitoring objectives is an evaluation of the impact of water and environmental management measures as well as climate change on nutrient transport. M type objectives typically involve the reaction of the catchment to man-made or natural changes of nutrient sources, and the hydrological functioning or the biogeochemistry of the system. We have defined three subgroups:

- M1: management and mitigation of point sources. Highfrequency monitoring can reveal any changes in the short-term reaction of the catchment to changes in nutrient inputs, hydrology, or biogeochemistry. Besides revealing the time-dependent nutrient inputs from, for instance, sewage treatment facilities or leaking septic tanks (Wade et al., 2012a), the effects of mitigating measures can be followed by assessing changes in the duration or frequency of nutrient peaks in the time series before and after their implementation. Examples are given in Campbell et al. (2015) and Greene et al. (2011).

- M2: management and mitigation of diffuse sources. Mitigation measures for nutrients in agricultural areas typically involve some kind of land use management or changes in the hydrological functioning of the system. Despite the establishment of high-frequency monitoring, the effects of mitigation measures are often difficult to separate from those of natural variability created by meteorological conditions or from spatial variations in governing variables such as soil types and subsurface reactivity. Examples of monitoring the effects of mitigation measures in diffuse pollution settings are given in Campbell et al. (2015), Ernstsen et al. (2015), Van der Grift et al. (2016), and Rozemeijer et al. (2016), all included in this special issue, and Greene et al. (2011). Given the slower dynamics of groundwater, other techniques such as age dating and lower monitoring frequencies are usually applied to reveal trends following implementation of mitigation measures (Broers and Van der Grift, 2004; Visser et al., 2007, 2009; Hansen et al., 2012a, b, 2013).

- M3: climate change and mitigation measures. Highfrequency monitoring helps reveal the impact of and adaptations to climate change by capturing changes in the hydrological and hydro chemical response to rainfall events and testing whether the projected changes in catchment behaviour actually occur. Examples are given in Graeber et al. (2015) and Goyenola et al. (2015).

\section{Information timescales}

The scale at which information is required is termed "information scale". Information scale is important when designing monitoring systems and choosing the methods and goals for data processing (Broers, 2002; Van Geer et al., 2006). For instance, selection of monitoring equipment and choice of methods for data smoothing require a properly defined information scale, and the papers and abstracts are therefore grouped according to this (Table 1). For each monitoring objective, the required information depends on the scale at which the information is needed. The following three temporal scales are considered:

- short-scale dynamics and extreme events (minutes to weeks);

- seasonal and annual patterns (months to several years);

- longer-term behaviour and trends (years to decades).

Specific monitoring objectives may require a specific information scale. This we illustrate for the monitoring objective "characterizing groundwater surface water interaction". Typically, analysis of the response of nitrate concentrations in surface water to rainfall events is of short temporal scale (minutes or hours). To estimate average loads from shallow groundwater towards surface water during the growing season, the information scale required will involve one or several seasons. To evaluate the long-term sustainability of groundwater-dependent aquatic ecosystems in a WFD assessment, the information scale may cover several years or decades.

Irrespective of the timescale of the monitoring objective, observations contain variations at all timescales and the gathered data have to be processed and statistically filtered in order to obtain the correct trend information or system characteristics at the desired timescale (e.g. Lloyd et al., 2014). 


\subsection{Short timescales}

Obviously, to obtain information at short timescales, highfrequent monitoring is required and data processing will include high-pass filters. Concentrations and loads of nutrients frequently show rapid changes over time as a result of rainfall events, emissions of effluents from point sources and unintended losses of manure or pesticides during application. Often, these rapid changes occur at timescales of less than $1 \mathrm{~h}$ and high-frequency monitoring is required in order to capture peaks and extreme values that would go undetected if applying only low-frequency monitoring (cf. Campbell et al., 2015; Skeffington et al., 2015; Van der Grift et al., 2016).

Also, if assessing the statistical characteristics of the concentration or the load of a solute (e.g. average and percentile values or the frequency of exceedance of a threshold), highfrequency monitoring is a valuable tool. In principle, statistical characteristics can be determined from low-frequency observations provided that the monitoring period is sufficiently long. However, in many cases the system shows statistically non-stationary behaviour over longer periods of time due to, for example, changes in land use management. Highfrequency monitoring enables the estimation of trend characteristics in shorter periods, being less sensible for longerterm trends (e.g. Lloyd et al., 2014). Many studies focus on the interactions between groundwater and surface water, in particular the different flow paths of nutrients towards the surface water (cf. Poulsen et al., 2015b; Rozemeijer et al., 2010b). The weather conditions appear to be the major driving force for the temporal distribution of fluxes along the different flow paths, including quick components like discharges from point sources, tile drain water, and overland flow and slow components such as discharges from deeper groundwater. The quick components have response times of the order of magnitude of hours, days, or weeks. Therefore, the response of nutrient fluxes and loads to precipitation is a complex function (e.g. Van der Velde et al., 2010). To estimate this complex response function and to unravel the contributions of the different flow paths, high-frequency monitoring is a prerequisite (cf. Campbell et al., 2015).

\subsection{Seasonal and annual patterns and long-term behaviour}

An example of an objective with a seasonal information scale is the estimation of average or typical nutrient concentrations during the growing season. An example of a longterm monitoring objective is found in the WFD, which includes elucidating the trends in water quality status towards the 2027 compliance with good chemical status and meeting the environmental objectives for aquatic and terrestrial ecosystems (cf. Rozemeijer et al., 2014; Erntsen et al., 2015; Skeffington et al., 2015). As with groundwater, an equivalent timescale is required for demonstrating the trend reversal in concentrations of nitrate (Visser et al., 2007). Although high- frequency information (days to weeks) is not required for the analysis of seasonal and annual patterns and long-term behaviour, high-frequency monitoring can be beneficial, because often statistical characteristics and input-response relations can be inferred reliable from a shorter monitoring period. Individual observations of water quality are the result of variation at a wide range of frequencies. High-frequency variations (noise) tend to obscure the low-frequency signal. High-frequency monitoring enables filtering out the noise (low-pass filter) during relatively short monitoring periods in order to elucidate the long-term trend (Bierkens et al., 1999; Halliday et al., 2012; Aubert et al., 2013; Lloyd et al., 2014; Van der Grift et al., 2016).

\section{Monitoring equipment}

Several types of sensors have been developed in recent years. Some are based on in situ laboratory (mobile or stationary) analysis of water samples, while others utilize, for instance, light or infrared (UV) spectra to measure chemical parameters (e.g. turbidity, nitrate, DOM) or materials capable of passive adsorption of chemicals (e.g. SorbiCells). Some sampling methods produce point observations in time, whereas others derive flow- or time-weighted concentrations over a time period. A number of studies (e.g. Rozemeijer et al., 2010c; Cassidy and Jordan, 2011; Jordan et al., 2013; Huebsch et al., 2015) compare several sampling instruments and monitoring strategies (Table 2). Various continuous monitoring methods, in particular those described in the papers presented in this special issue, are listed in Table 2.

\section{Conclusions and future outlook}

Based on the observations and findings described at the five EGU sessions together with the 10 papers included in the present special issue, some general conclusions can be drawn.

Several research groups in Europe and beyond are undertaking pilot studies on the use of high-frequency monitoring of nutrients. During the past decades, there has been growing awareness of the fact that the quality of the aquatic environment is threatened by high concentrations and loads of nutrients in groundwater and surface water. At the same time, development of observation equipment enabling highfrequency monitoring at affordable cost has been extensive and, accordingly, assessment and quantification of the dynamic behaviour of nutrients at very small timescales (minutes to hours) are now feasible. Most testing has been devoted to process understanding (PU) and quantification of concentrations and loads (Q) (Table 1). Quantification of concentrations and loads to be used in the status assessments required by the EU Water Framework Directive has received much attention by several European research groups during the last five years. However, only few papers and con- 
Table 2. Overview of monitoring methods and instruments applied in the session abstracts and special issue papers.

\begin{tabular}{|c|c|c|}
\hline Monitoring methods & Instruments & $\begin{array}{l}\text { References to papers in } \\
\text { the special issue } \\
\text { describing the results } \\
\text { of studies in which } \\
\text { the instruments were } \\
\text { applied }\end{array}$ \\
\hline Nitrate sensors & $\begin{array}{l}\text { - scan spectrolyser }{ }^{\mathrm{TM}} \text {, scan } \\
\text { Messtechnik GmbH, Austria } \\
\text { - NITRATAX plus sc, Hach Lange GmbH, } \\
\text { Germany } \\
\text { - reagentless hyperspectral UV } \\
\text { photometer (ProPS) }\end{array}$ & $\begin{array}{l}\text { Huebsch et al. (2015) } \\
\text { Van der Grift et al. (2016) } \\
\text { Rozemeijer et al. (2010c) } \\
\text { Wade et al. (2012a) } \\
\text { Heinz et al. (2014) }\end{array}$ \\
\hline Phosphorus (total $\mathrm{P}$, total reactive $\mathrm{P}$ ) & $\begin{array}{l}\text { Phosphax Sigma auto-analyzer, Hach } \\
\text { Lange GmbH, Düsseldorf, Germany } \\
\text { C }\end{array}$ & $\begin{array}{l}\text { Campbell et al. (2015) } \\
\text { Rozemeijer et al. (2016) } \\
\text { Skeffington et al. (2015) } \\
\text { Van der Grift et al. (2016) }\end{array}$ \\
\hline $\begin{array}{l}\text { Total reactive phosphorus (TRP), } \\
\text { nitrite }\left(\mathrm{NO}_{2}\right) \text { and ammonium } \\
\left(\mathrm{NH}_{4}\right)\end{array}$ & Systea Micromac C & Wade et al. (2012a) \\
\hline Passive samplers & SorbiCell samplers & $\begin{array}{l}\text { Rozemeijer et al. (2010c, 2016) } \\
\text { Audet et al. (2014) }\end{array}$ \\
\hline $\begin{array}{l}\text { Turbidity } \\
\text { Automatic samplers }\end{array}$ & $\begin{array}{l}\text { OBS sensor, Campbell Scientific } \\
\text { Isco sampler; Sigmatax sampler }\end{array}$ & $\begin{array}{l}\text { Van der Grift et al. (2016) } \\
\text { Goyenola et al. (2015) } \\
\text { Audet et al. (2014) } \\
\text { Van der Grift et al. (2016) }\end{array}$ \\
\hline $\begin{array}{l}\mathrm{O}_{2}, \mathrm{pH} \text {, temperature conductivity, } \\
\text { turbidity, and chlorophyll }\end{array}$ & - YSI 6600 multi-parameter sonde & $\begin{array}{l}\text { Skeffington et al. (2015) } \\
\text { Wade et al. (2012a) }\end{array}$ \\
\hline Conductivity, temperature & $\begin{array}{l}\text { CTD diver (Van Essen Instruments, } \\
\text { Delft, the Netherlands) }\end{array}$ & Van der Grift et al. (2016) \\
\hline${ }^{18} \mathrm{O},{ }^{2} \mathrm{H}$ & $\begin{array}{l}\text { Wavelength-Scanned Cavity Ring Down } \\
\text { Spectrometry System (WS-CRDS) } \\
\text { L2120-i Picarro }\end{array}$ & Heinz et al. (2014) \\
\hline
\end{tabular}

tributions cover aspects of the monitoring effects of river basin management plans that have been implemented to reduce pollution by nutrients or climate change impacts. Although full-scale application of high-frequency monitoring at national or regional scale may not always be reported in scientific papers, we believe that its use in operational water management is still limited. The papers listed in Table 1 show that different monitoring methods have been successfully implemented and tested, and it is a step forward towards implementation of these kinds of applications in national or regional monitoring programmes in the coming years.

Some papers present comparisons between different observation methods and equipment, and others discuss the technical issues related to the observation devices, and it appears that sensors and other equipment have measurement errors differing from those of traditional laboratory analyses.
This may, for example, be due to the required regular calibration and the often high maintenance effort of equipment.

High-frequency monitoring produces time series that enable us to unravel the transport processes of nutrients, for example the contribution of different flow routes or the ratio between statistically stationary fluctuations and structural trends. The fast-growing amount of data requires development of new analysis techniques to handle the large data sets. The error statistics of the new equipment in combination with the large amount of data require also new techniques for QA/QC.

Research into high-frequency nutrient monitoring will continue. Here, we focus on the development expected for the near future.

Today, high-frequency monitoring of nutrients is subject to research and pilot studies, but we expect a transition from research to implementation in operational practice. This tran- 
sition requires the design of efficient and cost-effective monitoring programmes, for which research is needed to identify the best combination of observation devices and how to best integrate the data from these devices with dynamic models describing the evolution of nutrients in time and space. Welldefined monitoring objectives are a prerequisite for optimum monitoring strategies (observation devices, spatial and temporal distribution).

High-frequency monitoring will become part of the routine workflow of agencies within groundwater and surface water quality management, and vast amounts of data will be generated. Often long time series are necessary, for example to assess trends over longer periods of time. Therefore, a robust system for data storage, QA/QC and easy access data availability is of great importance (e.g. Neal et al., 2011). Today, data processing (e.g. to assess trends) is hampered by the short duration of the time series. However, with increasing availability of long time series, application of advanced statistical time-series analysis methods becomes feasible (Lloyd et al., 2014). We expect that more research will be conducted into the application of statistically based techniques, such as transfer function-noise models, to deduce the characteristics of the series and to quantify the relationship with other hydrological variables (e.g. Van der Grift et al., 2016). Examples of characteristics may be typical seasonal behaviour, the memory of the system, and the trend. Examples of relationships are the response of nutrients to meteorological variables or to water management. Such time-series analysis techniques will have applications in studying the effects of climate change on the functioning of catchments, e.g. by elucidating the changing response times of water and solutes towards precipitation and drought events.

High-frequency data will in the future assist in achieving a better understanding about in-stream processes such as nitrogen and phosphorus assimilation, sedimentation, and resuspension processes. Moreover, water quality models will be challenged when calibrated against high-frequency data, which in turn will force models to be more dynamic (run at lower time steps) and improve their internal process descriptions.

High-frequency monitoring data will also be able to assist water managers in getting a true picture of nutrient loadings and sources that will enable river basin managers to implement more targeted and thereby cost-effective decisions when fulfilling the requirement under the EU directives directed at water management such as the Water Framework Directive, the Nitrates Directive, and the Groundwater Directive.

The future will likely see more emphasis on multi-variable analysis, in which monitoring set-up, data collection, and data processing are not made for one variable at a time but within a multi-variate framework. Such a framework can include the dynamic modelling of travel times, the age dating of contributing flow routes (e.g. Gilmore et al., 2016), and the inclusion of other tracers of flow processes that can be monitored at high resolution, including isotopes of water $\left({ }^{18} \mathrm{O} /{ }^{2} \mathrm{H}\right)$ and products of radioactive decay in the subsurface (e.g. ${ }^{222} \mathrm{Rn}$ ).

Future research into observation devices will probably concentrate on the combination of different types of highfrequency sensors to improve our knowledge of biogeochemical processes, such as nitrate attenuation processes and phosphorus retention, in groundwater and surface waters. Development of equipment (sensors) will likely continue in the coming years, in particular to create cost-effective, more precise, more robust, and more low-maintenance monitoring devices.

\section{Data availability}

Acknowledgements. The work is a contribution to the BufferTech project under the Innovation Foundation in Denmark (grant no. 1305-00017B) and supported by the Strategic Research Funding of TNO.

Edited by: M. Giudici

Reviewed by: three anonymous referees

\section{References}

Aubert, A. H., Gascuel-Odoux, C., Gruau, G., Akkal, N., Faucheux, M., Fauvel, Y., Grimaldi, C., Hamon, Y., Jaffrézic, A., Lecoz-Boutnik, M., Molénat, J., Petitjean, P., Ruiz, L., and Merot, P.: Solute transport dynamics in small, shallow groundwater-dominated agricultural catchments: insights from a high-frequency, multisolute $10 \mathrm{yr}$-long monitoring study, Hydrol. Earth Syst. Sci., 17, 1379-1391, doi:10.5194/hess-17-13792013, 2013.

Aubert, A. H., Kirchner, J. W., Gascuel-Odoux, C., Faucheux, M., Gruau, G., and Mérot, P.: Fractal water quality fluctuations spanning the periodic table in an intensively farmed watershed, Environ. Sci. Technol., 48, 930-937, 2014.

Audet, J., Martinsen, L., Hasler, B., de Jonge, H., Karydi, E., Ovesen, N. B., and Kronvang, B.: Comparison of sampling methodologies for nutrient monitoring in streams: uncertainties, costs and implications for mitigation, Hydrol. Earth Syst. Sci., 18, 4721-4731, doi:10.5194/hess-18-4721-2014, 2014.

Bierkens, M. F., Knotters, M., and Van Geer, F. C.: Calibration of transfer function-noise models to sparsely or irregularly observed time series, Water Resour. Res., 35, 1741-1750, 1999.

Bieroza, M. and Heathwaite, L.: The value of automated highfrequency nutrient monitoring in inference of biogeochemical processes, temporal variability and trends, Geophys. Res. Abstr., 15, EGU2013-8300, 2013.

Bieroza, M. Z., Heathwaite, A. L., Mullinger, N. J., and Keenan, P. O.: Understanding nutrient biogeochemistry in agricultural catchments: the challenge of appropriate monitoring frequencies, Environ. Sci. Process. Impacts, 16, 1676-1691, 2014.

Blauw, A., Beninca, E., Laane, R., Greenwoord, N., and Huisman, J.: Dancing with the Tides: Fluctuations of Coastal Phy- 
toplankton Orchestrated by Different Oscillatory Modes of the Tidal Cycle, EGU General Assembly Conference Abstracts, 15, EGU2013-138660, 2013.

Botter, G., Bertuzzo, E., and Rinaldo, A.: Catchment residence and travel time distributions: The master equation, Geophys. Res. Lett., 38, L11403, doi:10.1029/2011GL047666, 2011.

Broers, H. P.: Strategies for regional groundwater quality monitoring, Nederlandse Geografische Studies 306, p. 231., http: //dspace.library.uu.nl/bitstream/handle/1874/37373/broers.pdf (last access: 5 September 2016), 2002.

Broers, H. P. and Van der Grift, B.: Regional monitoring of temporal changes in groundwater quality, J. Hydrol., 296, 192-220, 2004.

Broers, H. P., Rozemeijer, J., and Klein, J.: A national scale monitoring network for nutrients in agriculture dominated headwaters in the Netherlands, EGU General Assembly Conference Abstracts, 14, 8240, 2012.

Campbell, J. M., Jordan, P., and Arnscheidt, J.: Using highresolution phosphorus data to investigate mitigation measures in headwater river catchments, Hydrol. Earth Syst. Sci., 19, 453464, doi:10.5194/hess-19-453-2015, 2015.

Cassidy, R. and Jordan, P.: Limitations of instantaneous water quality sampling in surface-water catchments: comparison with nearcontinuous phosphorus time-series data, J. Hydrol., 405, 182193, 2011

Cassidy, R., Jordan, P., and Macintosh, K.: Comparisons of highfrequency nutrient flux data with passive and low frequency alternatives in Irish rivers, EGU General Assembly Conference Abstracts, 14, 7515, 2012.

De Jonge, H., Karydi, E., and Kronvang, B.: Test of a new passive sampler in running waters: SorbiCell, Geophys. Res. Abstr., 14, EGU2012-11470, 2012.

Ernstsen, V., Olsen, P., and Rosenbom, A. E.: Long-term monitoring of nitrate transport to drainage from three agricultural clayey till fields, Hydrol. Earth Syst. Sci., 19, 3475-3488, doi:10.5194/hess-19-3475-2015, 2015.

EU Directive 91/676/EEC: concerning the protection of waters against pollution caused by nitrates from agricultural sources, 1991.

EU Directive 2000/70/EC: The EU Water Framework Directive, 2000.

EU Directive 2006/118/EC: The EU Groundwater Directive, 2006.

EU Directive 2009/90/EC: The Monitoring Directive, 2009.

Faucheux, M., Fovet, O., Gruau, G., Jaffrézic, A., Petitjean, P., Gascuel-Odoux, C., and Ruiz, L.: Real time high frequency monitoring of water quality in river streams using a UV-visible spectrometer: interest, limits and consequences for monitoring strategies, Geophys. Res. Abstr., 15, EGU2013-9425, 2013.

Gilmore, T. E., Genereux, D. P., Solomon, D. K., and Solder, J. E.: Groundwater transit time distribution and mean from streambed sampling in an agricultural coastal plain watershed, North Carolina, USA, Water Resour. Res., 52, 2025-2044, doi:10.1002/2015WR017600, 2016.

Goyenola, G., Meerhoff, M., Teixeira-de Mello, F., GonzálezBergonzoni, I., Graeber, D., Fosalba, C., Vidal, N., Mazzeo, N., Ovesen, N. B., Jeppesen, E., and Kronvang, B.: Monitoring strategies of stream phosphorus under contrasting climatedriven flow regimes, Hydrol. Earth Syst. Sci., 19, 4099-4111, doi:10.5194/hess-19-4099-2015, 2015.
Graeber, D., Meerhof, M., Zwirnmann, E., Ovesen, N., Gelbrecht, J., Teixeira de Mello, F., González-Bergonzoni, I., Jeppesen, E., and Kronvang, B.: Amount, composition and seasonality of dissolved organic carbon and nitrogen export from agriculture in contrasting climates, Geophys. Res. Abstr., 16, EGU2014-7458, 2014.

Graeber, D., Goyenola, G., Meerhoff, M., Zwirnmann, E., Ovesen, N. B., Glendell, M., Gelbrecht, J., Teixeira de Mello, F., González-Bergonzoni, I., Jeppesen, E., and Kronvang, B.: Interacting effects of climate and agriculture on fluvial DOM in temperate and subtropical catchments, Hydrol. Earth Syst. Sci., 19, 2377-2394, doi:10.5194/hess-19-2377-2015, 2015.

Greene, S., Taylor, D., McElarney, Y. R., Foy, R. H., and Jordan, P.: An evaluation of catchment-scale phosphorus mitigation using load apportionment modelling, Sci. Total Environ., 409, 22112221, 2011.

Halliday, S. J., Wade, A. J., Skeffington, R. A., Neal, C., Reynolds, B., Rowland, P., Neal, M., and Norris, D.: An analysis of longterm trends, seasonality and short-term dynamics in water quality data from Plynlimon, Wales, Sci. Total Environ., 434, 186-200, 2012.

Halliday, S., Skeffington, R., Wade, A., Neal, C., Norris, D., and Kirchner, J.: Streamwater nitrate dynamics across decadal to subdaily timescales in an upland system in mid-Wales, Geophys. Res. Abstr., 16, EGU2014-12512, 2014a.

Halliday, S., Wade, A., Skeffington, R., Bowes, M., Gozzard, E., Palmer-Felgate, E., Newman, J., Jarvie, H., and Loewenthal, M.: The impact of sampling regime on the accuracy of water quality status classifications under the Water Framework Directive, Geophys. Res. Abstr., 16, EGU2014-12705, 2014b.

Hansen, B., Thorling, L., Dalgaard, T., and Erlandsen, M.: Trend Analyses of Nitrate in Danish Groundwater, EGU General Assembly Conference Abstracts, 14, 5696, 2012a.

Hansen, B., Dalgaard, T., Thorling, L., Sørensen, B., and Erlandsen, M.: Regional analysis of groundwater nitrate concentrations and trends in Denmark in regard to agricultural influence, Biogeosciences, 9, 3277-3286, doi:10.5194/bg-9-3277-2012, 2012 b.

Hansen, B., Thorling, L., Sørensen, B., Dalgaard, T., and Erlandsen, M.: How does the Danish Groundwater Monitoring Programme support statistical consistent nitrate trend analyses in groundwater?, EGU General Assembly Conference Abstracts, 15, 7672, 2013.

Heinz, E., Kraft, P., Buchen, C., Frede, H. G., Aquino, E., and Breuer, L.: Set up of an automatic water quality sampling system in irrigation agriculture, Sensors, 14, 212-228, 2013.

Hrachowitz, M., Fovet, O., Ruiz, L., and Savenije, H. H.: Transit time distributions, legacy contamination and variability in biogeochemical $1 / f \alpha$ scaling: how are hydrological response dynamics linked to water quality at the catchment scale?, Hydrol. Process., 29, 5241-5256, 2015.

Huebsch, M., Grimmeisen, F., Zemann, M., Fenton, O., Richards, K. G., Jordan, P., Sawarieh, A., Blum, P., and Goldscheider, N.: Technical Note: Field experiences using UV/VIS sensors for high-resolution monitoring of nitrate in groundwater, Hydrol. Earth Syst. Sci., 19, 1589-1598, doi:10.5194/hess-19-15892015, 2015.

Jomaa, S., Alsuliman, M., and Rode, M.: Turbidity-based methods for continuous estimates of suspended sediment, particulate car- 
bon, phosphorus and nitrogen fluxes, Geophys. Res. Abstr., 17, EGU2015-12915-1, 2015.

Jonczyk, J., Haygarth, P., Quinn, P., and Reaney, S.: The Influence of temporal sampling regime on the WFD classification of catchments within the Eden Demonstration Test Catchment Project, Geophys. Res. Abstr., 16, EGU2014-13271, 2014.

Jordan, P., Arnscheidt, A., McGrogan, H., and McCormick, S.: Characterising phosphorus transfers in rural catchments using a continuous bank-side analyser, Hydrol. Earth Syst. Sci., 11, 372381, doi:10.5194/hess-11-372-2007, 2007.

Jordan, P., Melland, A. R., Mellander, P. E., Shortle, G., and Wall, D.: The seasonality of phosphorus transfers from land to water: Implications for trophic impacts and policy evaluation, Sci. Total Environ., 434, 101-109, 2012.

Jordan, P., Cassidy, R., Macintosh, K. A., and Arnscheidt, J.: Field and laboratory tests of flow-proportional passive samplers for determining average phosphorus and nitrogen concentration in rivers, Environ. Sci. Technol., 47, 2331-2338, 2013.

Jordan, P., Melland, A. R., Shore, M., Mellander, P. E., Shortle, G., Ryan, D., Crockford, L., Macintosh, K. A., Campbell, J. M., and Arnscheidt, J.: The 'fine structure' of nutrient dynamics in rivers: ten years of study using high-frequency monitoring, EGU General Assembly Conference Abstracts, 16, 12387, 2014.

Kirchner, J. W., Feng, X., Neal, C., and Robson, A. J.: The fine structure of water-quality dynamics: the (high-frequency) wave of the future, Hydrol. Process., 18, 1353-1359, 2004.

Kronvang, B., Bøgestrand, J., Windolf, J., Ovesen, N., and Troldborg, L.: Background phosphorus concentrations in Danish groundwater and surface water bodies, EGU General Assembly Conference Abstracts, 15, 2249, 2013.

Lloyd, C. E. M., Freer, J., Johnes, P., Collins, A., and the Hampshire Avon DTC Team: A framework for analysing water quality observations to detect change in the context of natural variability and uncertainty, Geophys. Res. Abstr., 14, EGU2012-10813-1, 2012.

Lloyd, C. E. M., Freer, J., Johnes, P., Collins, A., and the Hampshire Avon DTC Team: Assessing the effects of sampling design on water quality status classification, Geophys. Res. Abstr., 15, EGU2013-13032, 2013.

Lloyd, C. E. M., Freer, J. E., Collins, A. L., Johnes, P. J., and Jones, J. I.: Methods for detecting change in hydrochemical time series in response to targeted pollutant mitigation in river catchments, J. Hydrol., 514, 297-312, 2014.

Melland, A. R., Mellander, P.-E., Murphy, P. N. C., Wall, D. P., Mechan, S., Shine, O., Shortle, G., and Jordan, P.: Catchment monitoring technologies to identify critical source areas and times for nitrate transfer to streams, Geophys. Res. Abstr., 14, EGU2012-9918, 2012.

Melland, A. R., Jordan, P., Murphy, P., Mellander, P., and Shortle, G.: A review of monitoring approaches and outcomes of surface water quality mitigation measures in meso-scale agricultural catchments, Geophys. Res. Abstr., 15, EGU2013-10446, 2013.

Neal, C., Reynolds, B., Norris, D., Kirchner, J. W., Neal, M., Rowland, P., and Lawlor, A.: Three decades of water quality measurements from the Upper Severn experimental catchments at Plynlimon, Wales: an openly accessible data resource for research, modelling, environmental management and education, Hydrol. Process., 25, 3818-3830, 2011.
Neal, C., Reynolds, B., Rowland, P., Norris, D., Kirchner, J. W., Neal, M., and Guyatt, H.: High-frequency water quality time series in precipitation and streamflow: From fragmentary signals to scientific challenge, Sci. Total Environ., 434, 3-12, 2012.

Oosterwoud, M., Keller, T., Musolff, A., Frei, S., Park, J.-H., and Fleckenstein, J. H.: Investigating DOC export dynamics using high-frequency instream concentration measurements, Geophys. Res. Abstr., 16, EGU2014-15385, 2014.

Outram, F. N., Lloyd, C. E. M., Jonczyk, J., Benskin, C. McW. H., Grant, F., Perks, M. T., Deasy, C., Burke, S. P., Collins, A. L., Freer, J., Haygarth, P. M., Hiscock, K. M., Johnes, P. J., and Lovett, A. L.: High-frequency monitoring of nitrogen and phosphorus response in three rural catchments to the end of the 20112012 drought in England, Hydrol. Earth Syst. Sci., 18, 3429 3448, doi:10.5194/hess-18-3429-2014, 2014.

Ovesen, N. B., Windolf, J., and Kronvang, B.: Monitoring runoff and nutrient transport in the coastal zone of a Danish lowland river, Geophys. Res. Abstr., 14, EGU2012-11357, 2012.

Ovesen, N. B., Windolf, J., and Kronvang, B.: Monitoring runoff and nutrient transport in the coastal zone of a Danish lowland river, Geophys. Res. Abstr., 15, EGU2013-2246, 2013.

Poulsen, J. B., Ovesen, N. B., Windolf, J., and Kronvang, B.: Water and nutrient transport in a tidal influenced Danish lowland river: monitoring strategies and model validation, Geophys. Res. Abstr., 16, EGU2014-15712, 2014.

Poulsen, J. R., Kronvang, B., Ovesen, N., Piil, K., and Hvid, S.: A new emission-based approach for regulation of $\mathrm{N}$ losses from agricultural areas to surface waters, Geophys. Res. Abstr., 17, EGU2015-9113, 2015a.

Poulsen, J. R., Sebok, E., Duque, C., Tetzlaff, D., and Engesgaard, P. K.: Detecting groundwater discharge dynamics from pointto-catchment scale in a lowland stream: combining hydraulic and tracer methods, Hydrol. Earth Syst. Sci., 19, 1871-1886, doi:10.5194/hess-19-1871-2015, 2015 b.

Quinn, P., Jonczyk, J., Owen, J., Barber, N., Adams, R., ODonnell, G., and EdenDTC Team: The role of high frequency monitoring in understanding nutrient pollution processes to address catchment management issues, Geophys. Res. Abstr., 17, EGU20156221-1, 2015.

Rode, M., Kiwel, U., Knoeller, K., and Zacharias, S.: A New Online Water Quality Monitoring System within the TERENO Hydrological Observatory "Bode", Germany, Geophys. Res. Abstr., 14, EGU2012-5790, 2012.

Rode, M., Knoeller, K., and Kiwel, U.: Investigating in-stream nitrogen removal at variable flow conditions using new optical sensors, Geophys. Res. Abstr., 15, EGU2013-4326, 2013.

Rode, M., Halbebel, S., Anis, M. R., and Weitere, M.: Coupling of primary production and diel nitrate dynamics in a eutrophic lowland river system in central Germany, Geophys. Res. Abstr., 16, EGU2014-9999, 2014.

Rozemeijer, J. C., Van der Velde, Y. C., Van Geer, F. C., De Rooij Torfs, P. J. J. F., and Broers, H. P.: Improving load estimates of $\mathrm{N}$ and $\mathrm{P}$ in surface waters by characterizing the concentration response to rainfall events, Environ. Sci. Technol., 44, 6305-6312, 2010a.

Rozemeijer, J. C., Van der Velde, Y., van Geer, F. C., Bierkens, M. F. P., and Broers, H. P.: Direct measurements of the tile drain and groundwater flow route contributions to surface water contamination: from field-scale concentration patterns in groundwater to 
catchment-scale surface water quality, Environ. Poll., 158, 35713579, 2010b.

Rozemeijer, J. C., van der Velde, Y., De Jonge, H., Broers, H. P., Van Geer, F. C., and Bierkens, M. F. P.: Application and Evaluation of a New Passive Sampler for Measuring Average Solute Concentrations in a Catchment Scale Water Quality Monitoring Study, Environ. Sci. Technol., 44, 1353-1359, 2010c.

Rozemeijer, J. C., Van der Velde, Y., Broers, H. P., and Van Geer, F. C.: Dynamics in surface water solute concentrations and consequences for water quality monitoring, Geophys. Res. Abstr., 14, EGU2012-5013, 2012.

Rozemeijer, J. C., Van der Velde, Y., Broers, H. P., and Van Geer, F. C.: Applications of continuous water quality monitoring techniques for more efficient water quality research and management, Geophys. Res. Abstr., 15, EGU2013-10264, 2013.

Rozemeijer, J. C., Klein, J., Broers, H. P., Van Tol-Leenders, T. P., and Van der Grift, B.: Water quality status and trends in agriculture-dominated headwaters; a national monitoring network for assessing the effectiveness of national and European manure legislation in The Netherlands, Environ. Monit. Assess., 186, 8981-8995, 2014.

Rozemeijer, J. C., Visser, A., Borren, W., Winegram, M., Van der Velde, Y., Klein, J., and Broers, H. P.: High-frequency monitoring of water fluxes and nutrient loads to assess the effects of controlled drainage on water storage and nutrient transport, Hydrol. Earth Syst. Sci., 20, 347-358, doi:10.5194/hess-20-3472016, 2016.

Schneider, P., Hetzenauer, H., and Doppler, T.: Towards improved water quality assessment: comparison of surface water sampling strategies, Geophys. Res. Abstr., 14, 13665, 2012.

Shrestha, R. R., Osenbrück, K., and Rode, M.: Assessment of catchment response and calibration of a hydrological model using high-frequency discharge-nitrate concentration data, Hydrol. Res., 44, 995-1012, 2013.

Skeffington, R. A., Halliday, S. J., Wade, A. J., Bowes, M. J., and Loewenthal, M.: Using high-frequency water quality data to assess sampling strategies for the EU Water Framework Directive, Hydrol. Earth Syst. Sci., 19, 2491-2504, doi:10.5194/hess-192491-2015, 2015.

Stadler, P., Vogl, W., Koschelnik, J., Epp, M., Lackner, M., Oismüller, M., Kumpan, M., Strauss, P., Sommer, R., RyzinskaPaier, G., Farnleitner, A. H., and Zessner, M.: Testing the applicability of rapid on-site enzymatic activity detection for surface water monitoring, Geophys. Res. Abstr., 17, EGU2015-10547, 2015.

Van der Grift, B., Broers, H. P., Berendrecht, W. L., Rozemeijer, J. C., Osté, L. A., and Griffioen, J.: High-frequency monitoring reveals nutrient sources and transport processes in an agriculturedominated lowland water system, Hydrol. Earth Syst. Sci., 20, 1851-1868, doi:10.5194/hess-20-1851-2016, 2016.

Van der Velde, Y. and Rozemeijer, J. C.: Continuous phosphorus measurements reveal catchment-scale transport processes, Geophys. Res. Abstr., 14, EGU2012-9066, 2012.

Van der Velde, Y., De Rooij, G. H., Rozemeijer, J. C., Van Geer, F. C., and Broers, H. P.: Nitrate response of a lowland catchment: on the relation between stream concentration and travel time distribution dynamics, Water Resour. Res., 46, W11534, doi:10.1029/2010WR009105, 2010. van der Vlugt, C., Yu, L., Rozemeijer, J., Van Breukelen, B., Ouboter, M., Stuurman, R., and Broers, H. P.: Dynamics in urban water quality: monitoring the Amsterdam city area, Geophys. Res. Abstr., 16, EGU2014-16346, 2014.

Van Geer, F. C., Bierkens, M. F. P., and Broers, H. P.: Groundwater Monitoring Strategies, Encyclopedia of Hydrological Sciences, doi:10.1002/0470848944.hsa316, 2006.

Vendelboe, A. L., De Jonge, H., Rozemeijer, J., and Wollesen-de Jonge, L.: Continuous Passive Sampling of Solutes from Agricultural Subsurface Drainage Tubes, Geophys. Res. Abstr., 17, EGU2015-14310, 2015.

Visser, A., Broers, H. P., and Bierkens, M. F. P.: Demonstrating trend reversal in groundwater quality in relation to time of recharge determined by $3 \mathrm{H} / 3 \mathrm{He}$ dating, Environ. Poll., 148, $797-$ $807,2007$.

Visser, A., Dubus, I. Broers, H. P., Brouyère, S., Korcz, M., Orban, P., Goderniaux, P., Batlle-Aguilar, J., Surdyk, N., Amraoui, N., Job, H., Pinault, J. L., and Bierkens, M.: Comparison of methods for the detection and extrapolation of trends in groundwater quality, J. Environ. Monit., 11, 2030-2043, 2009.

Wade, A. J., Palmer-Felgate, E. J., Halliday, S. J., Skeffington, R. A., Loewenthal, M., Jarvie, H. P., Bowes, M. J., Greenway, G. M., Haswell, S. J., Bell, I. M., Joly, E., Fallatah, A., Neal, C., Williams, R. J., Gozzard, E., and Newman, J. R.: Hydrochemical processes in lowland rivers: insights from in situ, highresolution monitoring, Hydrol. Earth Syst. Sci., 16, 4323-4342, doi:10.5194/hess-16-4323-2012, 2012a.

Wade, A. J., Skeffington, R. A., Halliday, S., Bowes, M. J., PalmerFelgate, E. J., Loewenthal, M., Jarvie, H. P., Neal, C., Reynolds, B., Norris, D., Gozzard, E., Newman, J., Greenway, G., Bell, I., Joly, E., and Haswell, S. J.: Hourly to seasonal hydrochemical dynamics in lowland and upland UK river-systems: from process inference to progress in hydrochemical modelling, Geophys. Res. Abstr., 14, EGU2012-13498-1, 2012b.

Wade, A., Palmer-Felgate, E., Halliday, S., Skeffington, R., Loewenthal, M., Jarvie, H., and Joly, E.: New insights into hydrochemical processes in lowland river systems gained from in situ, high-resolution monitoring, Geophys. Res. Abstr., 15, 7608, 2013.

Windolf, J., Thodsen, H., Troldborg, L., Larsen, S. E., Bøgestrand, J., Ovesen, N. B., and Kronvang, B.: A distributed modelling system for simulation of monthly runoff and nitrogen sources, loads and sinks for ungauged catchments in Denmark, J. Environ. Monit., 13, 2645-2658, 2011.

Windolf, J., Bøgestrand, J., Blicher-Mathiesen, G., and Kronvang, B.: Background nitrogen concentrations in fresh waters in Denmark, EGU General Assembly Conference Abstracts, 15, 2252, 2013.

Windolf, J., Kronvang, B., Carstensen, J., Larsen, S. E., Bøgestrand, J., and Trolle, D.: Monitoring of phosphorus in Danish surface waters 1990-2012: Trends in phosphorus loading and phosphorus concentrations in streams, lakes and estuaries, Geophys. Res. Abstr., 16, 15978, 2014.

Yu, L., van der Vlugt, C., Rozemeijer, J. C., Broers, H. P., van Breukelen, B., Ouboter, M., and Stuyfzand, P.: Landscape characteristics impacts on water quality of urban lowland catchments: monitoring the Amsterdam city area, Geophys. Res. Abstr., 17, 14332,2015 